\title{
Hydrolysis of Trivalent Holmium in Aqueous Solutions of 2 M Ionic Strength by Spectrophotometric and Potentiometric Methods
}

\author{
Miguel Angel Hernández-García1,2, Hilario López-González ${ }^{1 *}$, Alberto Rojas-Hernández² \\ ${ }^{1}$ Departamento de Química, Gerencia de Ciencias Básicas, Dirección de Investigación Científica, Instituto \\ Nacional de Investigaciones Nucleares, México D.F., México \\ ${ }^{2}$ Área de Química Analítica, Departamento de Química, Universidad Autónoma Metropolitana-Iztapalapa, \\ México D.F., México \\ Email: "ilario.lopez@inin.gob.mx, suemi918@xanum.uam.mx
}

Received 25 March 2015; accepted 25 April 2015; published 29 April 2015

Copyright (C) 2015 by authors and Scientific Research Publishing Inc.

This work is licensed under the Creative Commons Attribution International License (CC BY). http://creativecommons.org/licenses/by/4.0/

(c) (i) Open Access

\section{Abstract}

The first hydrolysis constants of trivalent holmium in $2 \mathrm{M} \mathrm{NaClO}_{4}$ and $2 \mathrm{M} \mathrm{NaCl}$ at $303 \mathrm{~K}$ and in $\mathrm{CO}_{2}$ free conditions were determined. The $\mathrm{pC}_{\mathrm{H}}$ borderlines of precipitation and first hydrolysis were determined by means of a spectrophotometric method and last one with the program SQUAD. Independently, the stability constant for the first hydrolytic species was determined, by means of potentiometric $\mathrm{pH}$ titrations whose data were treated with the program SUPERQUAD. The hydrolysis constants obtained were: $\log ^{*} \beta_{1, \mathrm{H}}=-8.02 \pm 0.05$ in $2 \mathrm{M} \mathrm{NaClO}_{4}$ and

$\log ^{*} \beta_{1, \mathrm{H}}^{\prime}=-8.16 \pm 0.04$ in $2 \mathrm{M} \mathrm{NaCl}$. These values attained by both methods are the same. The $\log _{10} \beta_{1, \mathrm{Cl}}$ constants for the species $\mathrm{HoCl}^{2+}$ was also calculated for $2 \mathrm{M}$ ionic strength and $303 \mathrm{~K}$ from the hydrolysis constant obtained in both perchlorate and chloride media. This value was $\log \beta_{1, \mathrm{Cl}}=$ -0.56 .

\section{Keywords}

Holmium, Hydrolysis, Spectrophotometric, Potentiometric, Chloride of Holmium Specie

\footnotetext{
${ }^{*}$ Corresponding author.
}

How to cite this paper: Hernández-García, M.A., et al. (2015) Hydrolysis of Trivalent Holmium in Aqueous Solutions of 2 M lonic Strength by Spectrophotometric and Potentiometric Methods. Advances in Materials Physics and Chemistry, 5, 161170. http://dx.doi.org/10.4236/ampc.2015.55017 


\section{Introduction}

The behavior of $\mathrm{Ho}^{3+}$ ions in aqueous solution is of increasing interest because the holmium is an excellent radiolanthanide have a range of half-lives and beta energies suitable for radiotherapy [1] and is analogue with Einsteinium, because the lanthanides are used as analogues for radioactive trivalent actinides [2]. Producing and accumulating of significant quantities of lanthanides during nuclear fission in uranium and Plutonium reactors are a potential source of their formation [3]. The knowledge of the hydrolysis constants of these elements allows the comprehensive modeling of radionuclide transport around proposed radioactive waste storage [4]. The deposition of non-or radioactive wastes in subsurface repositories of salt beds or ocean can be produce complexation with hydrofilic ligand, because complexation strongly affects their mobility [2]. This is the reason for employing the ionic strength of $\mathrm{NaCl}$ and compare with the use of $\mathrm{NaClO}_{4}$.

The hydrolysis constants of holmium III are scarce; published data have been by determined by potentiometric titration, solvent extraction and spectrophotometric titration [5]-[7].

The scatter of data of the stability constants of the hydroxo forms of trivalent holmium element in aqueous solutions. This circumstance is reasonable for the wide scatter of experimental stability constants, which was observed even for a single element at the same ionic strength [7].

The $\left.\mathrm{pM}_{(\mathrm{aq})}\right) \mathrm{p} C_{\mathrm{H}}$ diagram allows for the determination saturated and unsaturated zones in a solution, also allows for the calculation of the $\mathrm{pC}_{\mathrm{H}}$ of precipitation $\left(\mathrm{pC}_{\mathrm{Hpp}}\right.$ ) and hydrolysis constants [8]-[11].

The fundamentals of hydrolysis of rare earth elements and the $\mathrm{pM}_{(\mathrm{aq})}-\mathrm{pC}_{\mathrm{H}}$ diagram are found elsewhere [8][10] and only the main definitions being included here. At the initial, the first hydrolysis constant is calculated using:

$$
{ }^{*} \beta_{1, \mathrm{H}}=\frac{\left[\mathrm{Ho}(\mathrm{OH})^{2+}\right]\left[\mathrm{H}^{+}\right]}{\left[\mathrm{Ho}^{3+}\right]}
$$

Considering the influence of a $2 \mathrm{M} \mathrm{NaCl}$ medium on hydrolysis equilibrium, the $\log _{10} \beta_{1, \mathrm{Cl}}$ values might be calculated from the hydrolysis constant values obtained in both the absence and the presence of chloride ions at the same ionic strength and temperature. In a solution of chloride ions as high as $2 \mathrm{M}$ [11]:

$$
\mathrm{Ho}^{\prime}=\mathrm{Ho}^{3+}+\mathrm{HoCl}^{2+}
$$

Then

$$
\mathrm{Ho}^{\prime}+\mathrm{HO}^{-} \rightleftarrows \mathrm{Ho}(\mathrm{OH})^{2+} \quad{ }^{*} \beta_{1, \mathrm{H}}^{\prime}=\frac{\left[\mathrm{Ho}(\mathrm{OH})^{2+}\right]}{\left[\mathrm{Ho}^{\prime}\right]\left[\mathrm{OH}^{-}\right]}
$$

and

$$
{ }^{*} \beta_{1, \mathrm{H}}^{\prime}=\frac{{ }^{*} \beta_{1, \mathrm{H}}}{1+\beta_{1, \mathrm{Cl}}\left[\mathrm{Cl}^{-}\right]}
$$

Finally

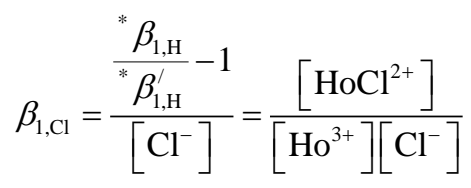

The determination of metal concentration in aqueous solutions by spectrophotometric and potentiometric methods can be used to calculate the equilibrium constants of dissolved elements in aqueous solutions, because the IUPAC recommends using two methods or more [2]. The spectrophotometric method allows for the determination the $\mathrm{pM}_{(\mathrm{aq})}-\mathrm{pC}_{\mathrm{H}}$ diagram, calculation of the $\mathrm{pC}_{\mathrm{H}}$ of precipitation $\left(\mathrm{pC}_{\mathrm{Hpp}}\right.$ ), and hydrolysis constants and potentiometric method using saturated and unsaturated zones determinated with the $\mathrm{pM}_{(\mathrm{aq})}-\mathrm{pC}_{\mathrm{H}}$ diagram. In addition, computer programs such as SQUAD (stability quotients from absorbance data) [12] and SUPERQUAD [13] have been developed to elucidate solution equilibria. All non linear least-squares methods (SQUAD and SUPERQUAD) are based on the minimization of function $\mathrm{U}$, given by Equation (5):

$$
\mathrm{U}=\sum(\Delta \mathrm{F})^{2}=\sum\left(\mathrm{E}_{\text {calculated }}-\mathrm{E}_{\text {experimental }}\right)^{2}
$$


The input file data for SQUAD and SUPERQUAD includes the $\mathrm{pH}$ measured, the metal concentration, and a chemical model that includes stoichiometry and estimated values of formation constants of the species present during titrations. The difference between these programs is that SQUAD utilizes the UV/Vis absorbance values, while SUPERQUAD utilizes the cell potential or $\mathrm{pH}$. Both programs provide the refined values of formation constants, as well as a very complete statistical analysis of the data.

In a previous study it has reported results of investigation of the hydrolysis of $\mathrm{La}$, Pr, and $\mathrm{Lu}$ in aqueous solutions using potentiometric method and different treatment of the data [11]. Hydrolysis and the stability constant of the chloride species of lanthanum, praseodymium and lutetium were determined for each element; all these studies were carried out in $2 \mathrm{M}$ sodium perchlorate and sodium chloride in a nitrogen atmosphere and at temperature of $303 \mathrm{~K}$.

This paper extends the study of the rare earth elements (REE) to holmium and, by using UV-Visible spectroscopy and potentiometric methods, permits reliable comparison of the hydrolysis of Ho with that of La, Pr, and $\mathrm{Lu}$. Here we report the results of an experimental investigation of the speciation of Ho in solution at temperatures of $303 \mathrm{~K}$.

The aim of the present research was to explore the influence of chloride ions on the solubility product of solid hydroxides and the first hydrolysis constants of trivalent holmium. The experimental conditions were $2 \mathrm{M}$ ionic strength, imposed with sodium perchlorate or chloride. The temperature was controlled at $303 \mathrm{~K}$ and the methods used were spectrophotometric and potentiometric. Data obtained were treated with both the program SQUAD and SUPERQUAD.

\section{Experimental}

All reagents were of analytical grade, and boiled deionized water being used to prepare the solutions. All prepared aqueous solutions contained either $2 \mathrm{M} \mathrm{NaClO}_{4}$ or $\mathrm{NaCl}$. Holmium (III) nitrate pentahydrate

[Ho( $\left(\mathrm{NO}_{3}\right)_{3}-5 \mathrm{H}_{2} \mathrm{O}$ ], 99.9\% Sigma-Aldrich Co. M.W. $=382.56 \mathrm{~g} / \mathrm{mol}$ was dissolved in $10^{-3} \mathrm{M}$ hydrochloric acid. The concentration of holmium in the standard solution was determined by titration with 0.025 M EDTA solution. Finally, three drops of pyridine and three drops of xylenol orange were added as an indicator [10]. The holmium concentration in the standard solution was $0.25 \mathrm{M}$. Starting from this solution, other solutions were made by dilution to obtain the calibration curves of holmium solution by UV-Vis spectrophotometry and for spectrophotometric titration.

For the preparation of the hydrochloric acid solutions, we started from $\mathrm{HCl} 1 \mathrm{M}$ (Merck, titrisol). Starting from this solution, all the others were prepared by dilution.

The standard solutions of sodium hydroxide were prepared in a glove box under a nitrogen atmosphere, by diluting the supernatant from a $50 \% \mathrm{w} / \mathrm{v}$ sodium hydroxide aqueous solution which had been centrifuged to separate the insoluble sodium carbonate [14]. The titration of the standard solutions with hydrochloric acid proved that they were free of carbonate ions. These solutions were used immediately, or were stored in the same glove box under a nitrogen atmosphere. The lids of the solution bottles had a trap containing ascarite as a $\mathrm{CO}_{2}$ absorbent. The concentration of sodium hydroxide of each stock solution was determined by titration with potassium hydrogen phthalate, the ionic strength being adjusted with $\mathrm{NaCl}$ or $\mathrm{NaClO}_{4}$.

\subsection{Determination of the $\mathrm{pC}_{\mathrm{H}}-\mathrm{pH}$ Relationship at $\mathrm{NaCl} 2 \mathrm{M}$ or $\mathrm{NaClO}_{4} 2 \mathrm{M}$}

Spectrophotometer and potentiometric calibration lines were obtained of solutions of $0.1,0.01$, and $0.001 \mathrm{M}$ sodium hydroxide and hydrochloride acid was prepared in $2 \mathrm{M}$ sodium perchlorate or sodium chloride ionic strength, as described elsewhere [10], and all $\mathrm{pH}$ measurements were corrected by means of the equations obtained:

$$
\begin{gathered}
\mathrm{pC}_{\mathrm{H}}=(0.95 \pm 0.005) \mathrm{pH}+(0.72 \pm 0.05)\left(r^{2}=0.998\right) \text { for } 2 \mathrm{M} \mathrm{NaClO}_{4} \\
\mathrm{pC}_{\mathrm{H}}=(1.00 \pm 0.02) \mathrm{pH}+(0.52 \pm 0.16)\left(r^{2}=0.999\right) \text { for } 2 \mathrm{M} \mathrm{NaCl}
\end{gathered}
$$

where $r$ is the correlation coefficient.

The $\mathrm{pH}$ measurements were carried out with a combined electrode system (glass-AgCl/Ag), which has low interference coefficients for alkali ions. A pH-meter (Radiometer TIM900 Titrilab), together with an automatic buret (Radiometer ABU901), a double-walled cell, and a constant-temperature circulator (Polyscience Circulator 
12101-10), were used to measure the $\mathrm{pH}$ with a precision of $0.001 \mathrm{pH}$ units. All the experiments were carried out at $(303.0 \pm 0.1) \mathrm{K}$, and a nitrogen flux was maintained in the reaction cell. The $\mathrm{pC}_{\mathrm{H}}$ of sodium perchlorate and sodium chloride stock solutions were adjusted to 3 with hydrochloric acid in order to prevent the hydrolysis of holmium element before the experiments began.

\subsection{Calibration Curves of Holmium Solution by UV-Vis Spectrophotometry}

To obtain the absorption calibration curves, $10 \mathrm{~cm}^{3}$ solutions of $0.125,0.0625,0.025,0.01,0.005,0.0025,0.001$, $0.0005,0.00025,0.0002$, and $0.0001 \mathrm{M}(\mathrm{pH}=3)$ were prepared using the $0.25 \mathrm{M}$ holmium standard solution. The absorbance spectra of the resulting solution were obtained in the range of $200-700 \mathrm{~nm}$ using a Perkin-Elmer UV/Vis Lambda 10 spectrophotometer (Fremont, CA).

The data treatment was processed with an Excel worksheet (Microsoft), to determine the relation absorbance in function to the wavelength.

\subsection{First Hydrolysis Constant Determination of Ho (III) by Spectrophotometric Method}

The photometric titrations were obtained by following a previously described methodology [2]. Briefly, a known volume of the $6.25 \times 10^{-2} \mathrm{M}$ Ho solution (initial $\mathrm{pH}=3$ ) was transferred into a titration double wall cell containing $20 \mathrm{~cm}^{3}$ of the $2 \mathrm{M} \mathrm{NaClO}_{4}$ or $\mathrm{NaCl}$ solution both at initial $\mathrm{pH}=3$ to prevent holmium hydrolysis. The transferred volume was enough to obtain a final Ho concentration of $2.5 \times 10^{-4} \mathrm{M}$. The initial solution was stired for thirty minutes before the spectrophotometric titrations started and nitrogen flux was kept on the solution during the experiment, after which the solution's $\mathrm{pH}$ was recorded. Subsequently, an aliquot of $3 \mathrm{~cm}^{3}$ was taken from the reaction double wall cell to determine the UV-Vis absorption, and the volume obtained was returned to the titration double wall cell. After that, a known volume of the $2.5 \times 10^{-3} \mathrm{M} \mathrm{NaOH}$ in $2 \mathrm{M} \mathrm{NaClO}_{4}$ or $\mathrm{NaCl}$ was added to the titration cell. After equilibration for 7 minutes, another aliquot was taken to determine the new $\mathrm{pH}$ and absorbance. The absorbances versus wavelength profiles of the resulting solutions were obtained in the range of 200 to $700 \mathrm{~nm}$. Addition of the $\mathrm{NaOH}$ solution, $\mathrm{pH}$, and absorbance measurement was repeated until the $\mathrm{pH}$ was about 10. A nitrogen flux was maintained on the solution during the experiments. At least two experiments were performed under the same conditions to obtain reproducibility. The experimental values of the $\mathrm{pC}_{\mathrm{H}}$, absorbance, and volumes of $\mathrm{NaOH}$ added in each titration point, were analyzed using the SQUAD [12] computer program, as well as the graphic method [2]. The absorbance versus $\mathrm{pC}_{\mathrm{H}}$ data were plotted using the Excel $^{\circledR}$.

\subsection{First Hydrolysis Constant Determination of Ho (III) by Potentiometric Method}

The experiments for the potentiometric titrations were carried out as follows: The concentrations of the solutions of holmium were $2.5 \times 10^{-4} \mathrm{M}$ and $2.5 \times 10^{-3} \mathrm{M}$ for sodium hydroxide in $2 \mathrm{M}$ sodium perchlorate or sodium chloride. The initial volume in the titration double wall cell was $20 \mathrm{~cm}^{3}$ of $2 \mathrm{M} \mathrm{NaClO}_{4}$ or $\mathrm{NaCl}$ both at $\mathrm{pH}=3$. The initial solution was stirred for thirty minutes before the potentiometric titrations started and nitrogen flux was kept on the solution during the experiment. The added volume of the sodium hydroxide solution (the aliquot volume was $20 \mathrm{~mm}^{3}$ ) and the $\mathrm{pH}$ measurements were recorded. The $\mathrm{pC}_{\mathrm{H}}$ values were calculated by the equations given above. The experiments were carried out at $303 \mathrm{~K}$ and at least three experiments being performed under the same conditions to analyze reproducibility. The Data were mathematically treated with the program SUPERQUAD in order to calculate the equilibrium constants.

\section{Results and Discussion}

\subsection{Absorbance versus Concentration Curves}

The UV-Vis absorbance vs. concentration curves of holmium standard solutions were obtained in the range 255 to $660 \mathrm{~nm}$ at pH 3 (Figure 1). Spectra for concentration ranging from $0.0001 \mathrm{M}$ and $0.0002 \mathrm{M}$ were not well defined and therefore discarded. In the present work, the lower detection limit was $0.00025 \mathrm{M}$. The concentrations ranging of the spectra were from 0.00025 to $0.25 \mathrm{M}$. Spectra have 11 wavelengths (301, 345, 361, 386, 417, 451, $468,473,485,537$, and $641 \mathrm{~nm})$. It can be noted that in the UV region (255 to $330 \mathrm{~nm}$ ) there is a wide band between $0.00025 \mathrm{M} \leq[\mathrm{Ho}(\mathrm{III})] \leq 0.125 \mathrm{M}$. For the absorption band of $301 \mathrm{~nm}$ (Figure 1), is to determine low 


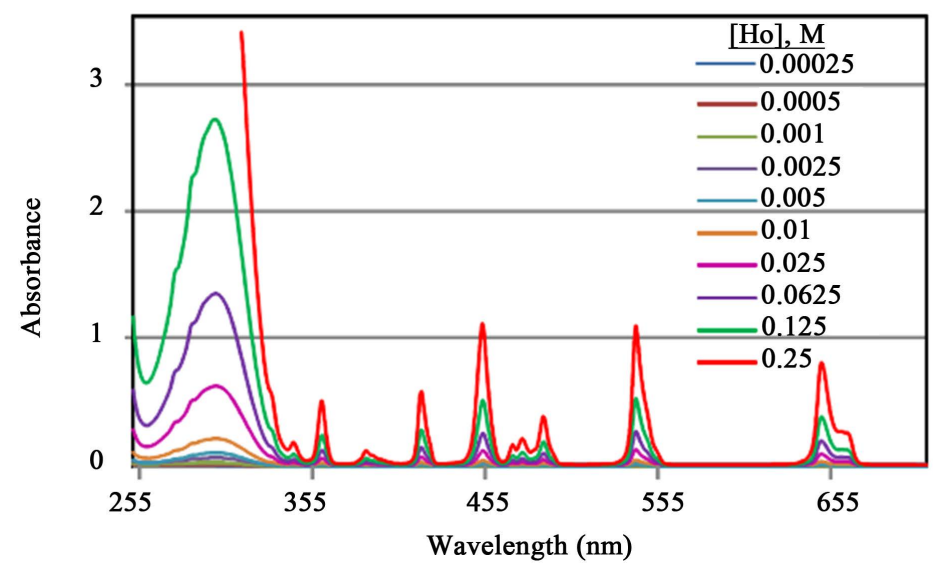

Figure 1. UV-Vis absorption spectra for each one of the solution of holmium (III) at pH 3, in the range $255-660 \mathrm{~nm}$.

concentration of holmium. On the other hand, we can determine high concentration of holmium in narrow absorption bands (346, 386 principally, 468, and $473 \mathrm{~nm}$ ) are observed between $0.0625 \mathrm{M} \leq[\mathrm{Ho}(\mathrm{III})] \leq 0.25 \mathrm{M}$ (Figure 1).

These results extend the range of holmium concentration that can be determined and are shown in Table 1 .

Theses equations will permit to extend the range to calculate concentration of holmium, but have a limitation as it should be noted that the optimal range for measuring the absorbance for the purpose of quantitative analysis, is between $0.02-1.5$.

\subsection{Spectrophotometric Method}

The values of the hydrolysis constants of $\mathrm{Ho}(\mathrm{III})$ were determined using UV-Vis titration in a $\mathrm{CO}_{2}$ free atmosphere at $303 \mathrm{~K}$. Figure 2 shows the UV-Vis absorption spectra of the titration of $0.00025 \mathrm{M} \mathrm{Ho}$ (III) with 0.0025 $\mathrm{M} \mathrm{NaOH}$ carried out in $2 \mathrm{M} \mathrm{NaClO}_{4}$ or $\mathrm{NaCl}$ at different $\mathrm{pC}_{\mathrm{H}}$ values. Each curve in Figure 2 represents the UVVis absorption spectrum of the Holmium solution at each titration $\mathrm{pC}_{\mathrm{H}}$. The UV-Vis absorption spectra overlapped in the regions of $301 \mathrm{~nm}$.

The absorption values in the range 280 to $325 \mathrm{~nm}$, the solution $\mathrm{pC}_{\mathrm{H}}$ (in the range 2.78 to $7.01 \mathrm{pC}_{\mathrm{H}}$, and the wavelength of $301 \mathrm{~nm}$ in $2 \mathrm{M} \mathrm{NaClO}_{4}$ are found and shown in Figure 2. These values in $2 \mathrm{M} \mathrm{NaClO}_{4}$, the range 4.36 to $6.80 \mathrm{pC}_{\mathrm{H}}$ in $2 \mathrm{M} \mathrm{NaCl}$, and the $\mathrm{Ho}(\mathrm{III})$ concentration were analyzed using the SQUAD computer program, as well as the graphic method.

\subsection{1. $\mathrm{pHo}_{(\mathrm{aq})}-\mathrm{pC}_{\mathrm{H}}$ Diagrams}

The $\mathrm{pHo}_{(\mathrm{aq})}-\mathrm{pC}_{\mathrm{H}}$ diagram (the absorbance-pC $\mathrm{C}_{\mathrm{H}}$ curves) for holmium in $2 \mathrm{M} \mathrm{NaCl}$ or $2 \mathrm{M} \mathrm{NaClO}_{4}$ at $303 \mathrm{~K}$ are shown in Figure 3. The absorbance of holmium in $20 \mathrm{~cm}^{3}$ of $2.5 \times 10^{-4} \mathrm{M}$ holmium solution was determined using a perking-Elmer UV-Vis Lambda 10 spectrophotometer (Fremont, CA).

Moreover, changes of holmium concentration because of the addition of sodium hydroxide solution must also be considered. Figure 3 shows that the experimental data follow the behavior predicted by the mentioned equation up to a certain $\mathrm{pC}_{\mathrm{H}}$ value. The inflection indicates the borderline between unsaturated and saturated zones.

This figure shows that the $\mathrm{pC}_{\mathrm{H}}$ for the precipitation beginning are $7.17 \pm 0.14$ in $2 \mathrm{M} \mathrm{NaCl}$ and $6.80 \pm 0.052$ $\mathrm{M} \mathrm{NaClO}_{4}$ respectively (Table 2). Although the diagrams obtained in both ionic strength were similar, a sudden increase of $\mathrm{pHo}_{(\mathrm{aq})}$ was observed at lower $\mathrm{pC}_{\mathrm{H}}$ values.

At this wavelength was calculated the first hydrolysis constant of holmium using the derivate graph, of its first derivative from absorbance-p $\mathrm{C}_{\mathrm{H}}$ curve. The maximum of the first derivative indicates an estimator of $\log * \beta_{1}$ value [15], because it signals the inflection point of the sigmoid absorbance-p $\mathrm{C}_{\mathrm{H}}$ curve. The estimator obtained by this graphic method is $\log ^{*} \beta_{1}=-8.16 \pm 0.02$ in $2 \mathrm{M} \mathrm{NaCl}$ and $\log ^{*} \beta_{1}=-8.02 \pm 0.01$ in $2 \mathrm{M} \mathrm{NaClO}_{4}$, respectively.

In this work, $\mathrm{pHo}_{(\mathrm{aq})}-\mathrm{pC}_{\mathrm{H}}$ diagrams were obtained from data corresponding to freshly precipitated holmium hydroxides. 


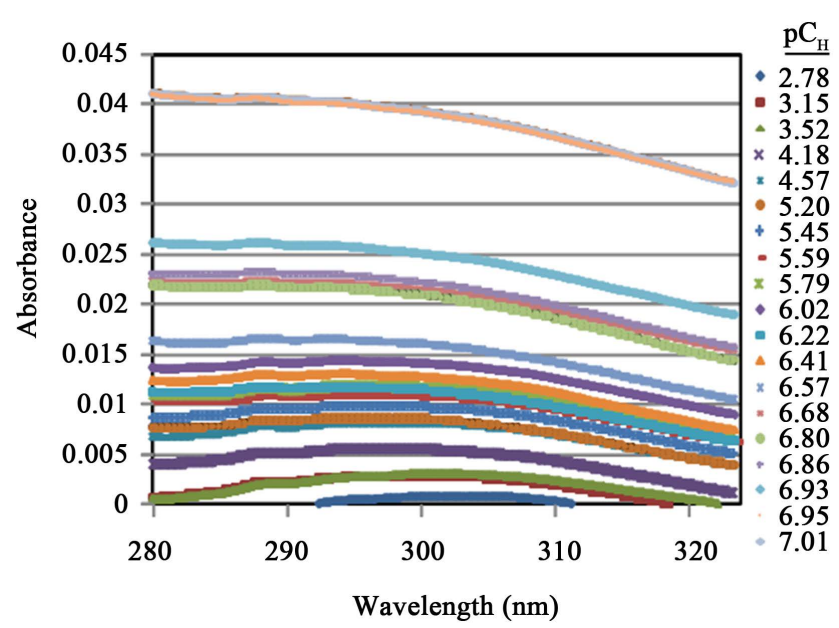

Figure 2. UV-Vis absorption spectra for the titration of holmium (III) $0.00025 \mathrm{M}$ with $\mathrm{NaOH} 0.0025 \mathrm{M}$ in $2 \mathrm{M} \mathrm{NaClO}_{4}$ at $303 \mathrm{~K}$.

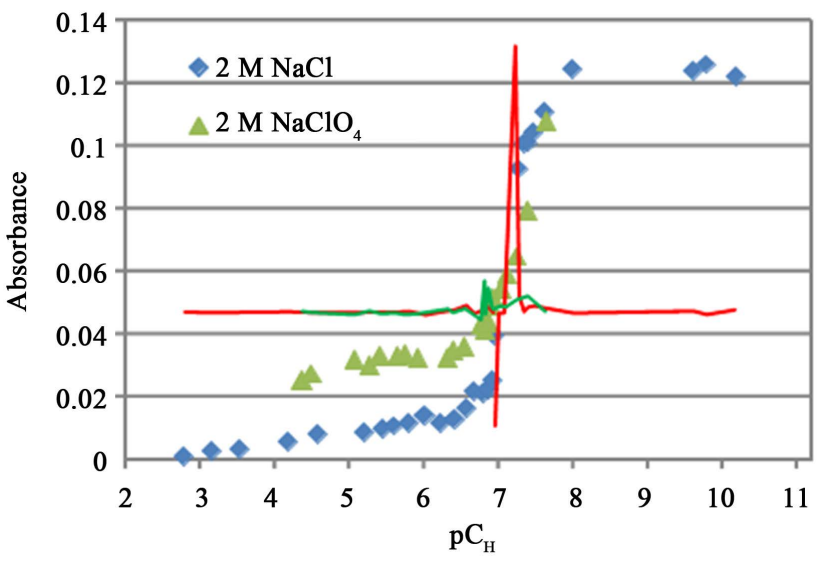

Figure 3. Curve of absorbance as a function of $\mathrm{pC}_{\mathrm{H}}$, in $2 \mathrm{M} \mathrm{NaClO}_{4}$ and $2 \mathrm{M} \mathrm{NaCl}$ at $303 \mathrm{~K}$, for wavelength of $301 \mathrm{~nm}$. The first derivative of this curve is represented with the solid line.

\subsubsection{Determination of the Hydrolysis Constants of Holmium(III) by SQUAD}

The computer program SQUAD [12] was used to confirm the first hydrolysis constant of Ho(III), as previously calculated with the $\mathrm{pHo}-\mathrm{pC} \mathrm{C}_{\mathrm{H}}$ diagram. SQUAD calculates overall stability constants values by mean of a nonlinear least-squares approach. The data for SQUAD calculations are: UV-Vis absorption data, Ho(III) concentration, and a chemical model to describe the system (i.e. $\mathrm{Ho}_{(\text {aq) }}^{3+}+\mathrm{H}_{2} \mathrm{O} \rightleftharpoons \mathrm{Ho}(\mathrm{OH})^{2+}+\mathrm{H}^{+}$). The hydrolysis constants of Ho(III) obtained using SQUAD were $\log _{10}{ }^{*} \beta_{1, \mathrm{H}}=-8.01 \pm 0.01$ in $2 \mathrm{M} \mathrm{NaClO}_{4}$ and $\log _{10}{ }^{*} \beta_{1, \mathrm{H}}^{\prime}=-8.17 \pm 0.02$ in $2 \mathrm{M} \mathrm{NaCl}$ (Table 2). The hydrolysis constants of Ho(III) calculated using SQUAD were very similar to the hydrolysis constants calculated using the $\mathrm{pHo}^{\mathrm{p}} \mathrm{C}_{\mathrm{H}}$ diagram in the same ionic strength [2] [10] [11], and different when ionic strength is different [11].

\section{3. pH Titration}

Figure 4 shows typical curves of $\mathrm{pH}$ titrations for holmium carried out in $2 \mathrm{M}$ sodium perchlorate and $2 \mathrm{M}$ sodium chloride. The data range used to feed the program SUPERQUAD was selected as follows: the initial point was taken immediately after the excess of acid was neutralized, i.e. where the first inflection of the titration curves was the highest. On the other hand, the end point was selected just before $\mathrm{Ho}(\mathrm{OH})_{3}$ precipitation started, according to the $\mathrm{pHo}_{(\mathrm{aq})}-\mathrm{pC}_{\mathrm{H}}$ diagrams. As mentioned above, all these determinations were carried out using a set of equipment. 


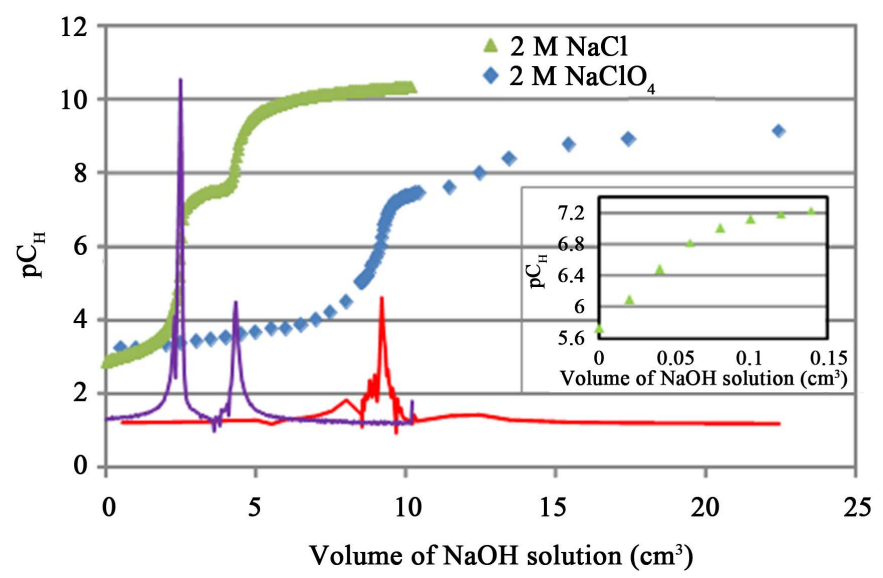

Figure 4. Typical titration curves of homium in $2 \mathrm{M} \mathrm{NaClO}_{4}$ and $2 \mathrm{M}$ $\mathrm{NaCl}\left(\left[\mathrm{Ho}^{3+}\right]_{\text {initial }}=2.5 \times 10^{-4} \mathrm{M} ;[\mathrm{NaOH}]=2.5 \times 10^{-3} \mathrm{M}\right)$. First derivative lines are included.

Table 1. Beer-Lambert law ranges of validity for the UV-Vis absorption bands of holmium(III) at pH 3.

\begin{tabular}{|c|c|c|c|c|c|c|}
\hline $\begin{array}{l}\text { Concentration range } \\
\text { of validity [M] }\end{array}$ & Wavelengths & Calibration equation & $\begin{array}{c}\text { Linearity range }[\mathrm{M}] \\
{[\mathrm{X}]_{\min }-[\mathrm{X}]_{\max }}\end{array}$ & $\begin{array}{c}\text { Sensibility } \\
{[\mathrm{M}]^{-1}} \\
\mathrm{~S} \pm \mathrm{Ss}\end{array}$ & $\begin{array}{c}\text { Limit of } \\
\text { detection }[\mathrm{M}] \\
\mathrm{LOD}=3 \mathrm{Sy} / \mathrm{m}\end{array}$ & $\begin{array}{c}\text { Limit of } \\
\text { quantification }[\mathrm{M}] \\
\mathrm{LOQ}=10 \mathrm{Sy} / \mathrm{m}\end{array}$ \\
\hline [0.001 - 0.0625] & $301 \mathrm{~nm}$ & $\begin{array}{c}\mathrm{A}=21.494[\mathrm{Ho}]+0.0152 \\
\mathrm{R}^{2}=0.9989\end{array}$ & {$[0.001]-[0.125]$} & $21.4 \pm 0.8$ & 0.005 & 0.017 \\
\hline \multirow{6}{*}{ [0.005 - 0.125] } & $361 \mathrm{~nm}$ & $\begin{array}{c}\mathrm{A}=2.01[\mathrm{Ho}]-0.003 \\
\mathrm{R}^{2}=0.9983\end{array}$ & {$[0.01]-[0.25]$} & $2.0 \pm 0.1$ & 0.013 & 0.046 \\
\hline & $417 \mathrm{~nm}$ & $\begin{array}{c}\mathrm{A}=2.29[\mathrm{Ho}]-0.001 \\
\mathrm{R}^{2}=0.9989\end{array}$ & {$[0.01]-[0.25]$} & $2.2 \pm 0.1$ & 0.011 & 0.037 \\
\hline & $451 \mathrm{~nm}$ & $\begin{array}{c}\mathrm{A}=4.62[\mathrm{Ho}]-0.052 \\
\mathrm{R}^{2}=0.9989\end{array}$ & {$[0.0625]-[0.25]$} & $4.6 \pm 1.9$ & 0.013 & 0.045 \\
\hline & $485 \mathrm{~nm}$ & $\begin{array}{c}\mathrm{A}=1.52[\mathrm{Ho}]-0.0003 \\
\mathrm{R}^{2}=0.9987\end{array}$ & {$[0.025]-[0.25]$} & $1.5 \pm 0.1$ & 0.013 & 0.044 \\
\hline & $537 \mathrm{~nm}$ & $\begin{array}{c}\mathrm{A}=4.32[\mathrm{Ho}]-3 \mathrm{E}-05 \\
\mathrm{R}^{2}=0.9993\end{array}$ & {$[0.005]-[0.25]$} & $4.3 \pm 0.1$ & 0.008 & 0.028 \\
\hline & $641 \mathrm{~nm}$ & $\begin{array}{c}\mathrm{A}=3.19[\mathrm{Ho}]-0.003 \\
\mathrm{R}^{2}=0.9988\end{array}$ & {$[0.01]-[0.25]$} & $3.1 \pm 0.2$ & 0.011 & 0.038 \\
\hline \multirow{4}{*}[0.0625->0.25\mathrm{M}]{} & $345 \mathrm{~nm}$ & $\begin{array}{c}\mathrm{A}=0.71[\mathrm{Ho}]+0.002 \\
\mathrm{R}^{2}=0.9999\end{array}$ & {$[0.025]-[0.25]$} & $0.71 \pm 0.07$ & 0.011 & 0.038 \\
\hline & $386 \mathrm{~nm}$ & $\begin{array}{c}\mathrm{A}=0.4723[\mathrm{Ho}]-0.0015 \\
\mathrm{R}^{2}=0.9999\end{array}$ & {$[0.0625]-[>0.25]$} & $0.47 \pm 0.05$ & 0.003 & 0.011 \\
\hline & $468 \mathrm{~nm}$ & $\begin{array}{c}\mathrm{A}=0.66[\mathrm{Ho}]-0.003 \\
\mathrm{R}^{2}=0.9998\end{array}$ & {$[0.0625]-[0.25]$} & $0.6 \pm 0.1$ & 0.006 & 0.020 \\
\hline & $473 \mathrm{~nm}$ & $\begin{array}{c}\mathrm{A}=0.82[\mathrm{Ho}]+0.0001 \\
\mathrm{R}^{2}=0.9986\end{array}$ & {$[0.025]-[0.25]$} & $0.82 \pm 0.09$ & 0.013 & 0.045 \\
\hline
\end{tabular}

Where: $\mathrm{nm}=$ nanometer, $\mathrm{A}=$ Absorbance, $[\mathrm{Ho}(\mathrm{III})]=$ holmium concentration, $\mathrm{R}^{2}=$ correlation coefficient, $\mathrm{m}=$ slope, Sy $=$ Linear regression standard error.

Table 2. $\mathrm{pC}_{\mathrm{H}}$ borderlines of precipitation, first hydrolysis constants in molarity units for holmium (III), in $2 \mathrm{M}_{\text {aqueous }} \mathrm{NaClO}_{4}$ $\left(\log _{10} * \beta_{1, \mathrm{H}}\right)$ and $2 \mathrm{M}$ aqueous $\mathrm{NaCl}\left(\log _{10}{ }^{*} \beta_{1, \mathrm{H}}^{\prime}\right)$ at $303 \mathrm{~K}$, from (A) $\mathrm{pHo}_{(\mathrm{aq})}-\mathrm{pC}_{\mathrm{H}}$ diagrams, (B) spectrophotometric titration and SQUAD program,(C) $\mathrm{pH}$ titration and SUPERQUAD program. Mean values of these calculations are also included (D).

\begin{tabular}{|c|c|c|c|c|c|c|c|c|c|}
\hline \multirow[b]{3}{*}[\mathrm{Ho}]{} & \multicolumn{6}{|c|}{$\mathrm{Ho}_{(\mathrm{aq})}^{3+}+\mathrm{H}_{2} \mathrm{O}(\mathrm{l}) \rightleftarrows \mathrm{Ho}(\mathrm{OH})_{(\mathrm{aq})}^{2+}+\mathrm{H}_{(\mathrm{aq})}^{+}$} & \multirow{2}{*}{\multicolumn{2}{|c|}{ Program SQUAD }} & \multirow[b]{3}{*}{$\begin{array}{c}\text { Average } \\
\text { values }\end{array}$} \\
\hline & \multicolumn{4}{|c|}{ Program SUPERQUAD } & & & & & \\
\hline & $\begin{array}{c}\text { Ionic } \\
\text { strength }\end{array}$ & $\mathrm{pC}_{\mathrm{H}}$ & $\mathrm{pC}_{\mathrm{H}}$ range & $\begin{array}{l}\log ^{*} \beta_{1, \mathrm{H}} \\
\log ^{*} \beta_{1, \mathrm{H}}^{\prime}\end{array}$ & $\sigma$ & $\mathrm{X}^{2}$ & $\mathrm{pC}_{\mathrm{H}}$ range & $\begin{array}{l}\log ^{*} \beta_{1, \mathrm{H}} \\
\log ^{*} \beta_{1, \mathrm{H}}^{\prime}\end{array}$ & \\
\hline $2.5 \times 10^{-4} \mathrm{M}$ & $2 \mathrm{M} \mathrm{NaClO}_{4}$ & $6.80 \pm 0.05$ & {$[5.53-6.43]$} & $-8.01 \pm 0.07$ & 8.90 & 4.00 & $4.36-7.64$ & $-8.02 \pm 0.02$ & $-8.01 \pm 0.05$ \\
\hline $2.5 \times 10^{-4} \mathrm{M}$ & $2 \mathrm{M} \mathrm{NaCl}$ & $7.17 \pm 0.14$ & {$[5.70-7.32]$} & $-8.16 \pm 0.02$ & 5.69 & 4.00 & $5.19-7.34$ & $-8.17 \pm 0.01$ & $-8.16 \pm 0.04$ \\
\hline
\end{tabular}


Determination of the Hydrolysis Constants of Holmium(III) Using SUPERQUAD

The computer program SUPERQUAD [13] was used to confirm the hydrolysis constants of Ho(III). The data for the SUPERQUAD calculations are $\mathrm{Ho}(\mathrm{III})$ concentration, volume of $\mathrm{NaOH}$ added at each point in the system, the $\mathrm{pC}_{\mathrm{H}}$ measured, and the chemical model to describe the system given above.

The hydrolysis constants of Ho(III) obtained using SUPERQUAD were $\log _{10}{ }^{*} \beta_{1, \mathrm{H}}^{\prime}=-8.17 \pm 0.02$ in $2 \mathrm{M}$ $\mathrm{NaCl}$, and $\log _{10}{ }^{*} \beta_{1, \mathrm{H}}=8.02 \pm 0.07$ in $2 \mathrm{M} \mathrm{NaClO}_{4}$ (Table 2).

Table 2 shows the Brönsted first hydrolysis constants for holmium in $2 \mathrm{M}$ sodium perchlorate and $2 \mathrm{M}$ sodium chloride, which were calculated by taking $\mathrm{K}_{\mathrm{w}}$ as a constant $\left(\log _{10} \mathrm{~K}_{\mathrm{w}}=-13.72\right.$ for $2 \mathrm{M} \mathrm{NaClO}_{4}$ and $\log _{10} \mathrm{~K}_{\mathrm{w}}$ $=-13.68$ for $2 \mathrm{M} \mathrm{NaCl}$ ). Statistical parameters of the SUPERQUAD program were $\sigma_{\text {total }}$ between 1.99 and 16.01 and $\chi^{2} 4.0$ and 10.0 , in both case.

As shown in Table 2, the hydrolysis constants of Ho(III) calculated with SUPERQUAD was very similar to the hydrolysis constants calculated using the computer program SQUAD [12] and the $\mathrm{pHo}_{(\mathrm{aq})}-\mathrm{pC}_{\mathrm{H}}$ diagram [8][12] in both ionic strength.

As describe elsewhere [11], data of Table 2 show that for a given element ${ }^{*} \beta_{1, \mathrm{H}}>{ }^{*} \beta_{1, \mathrm{H}}^{\prime}$, this behavior can be explained by the high concentration of chloride ions present in these solutions.

The same table shows that [11], the $\mathrm{pC}_{\mathrm{H}}$ borderline of precipitation is lower in $\mathrm{NaClO}_{4}$ than in $\mathrm{NaCl}$ solution. This behavior can be explained by the formation of the soluble $\mathrm{HoCl}^{2+}$ specie in the system, due to the high concentration of chloride ions when working in $2 \mathrm{M} \mathrm{NaCl}$. Chloride ions compete with hydroxyl ions for the complex formation with rare earth elements and the $\mathrm{pC}_{\mathrm{H}}$ borderlines of precipitation are thus higher in the presence of chloride ions than in their absence [11].

The first hydrolysis constant for Ho(III) $\left(\log _{10}{ }^{*} \beta_{1, \mathrm{H}}=-8.01 \pm 0.05\right.$ and $\left.\log _{10}{ }^{*} \beta_{1, \mathrm{H}}^{\prime}=-8.17 \pm 0.02\right)$ calculated in $2 \mathrm{M} \mathrm{NaClO}_{4}$ and $2 \mathrm{M} \mathrm{NaCl}$ ionic strength and with the data reported elsewhere [11] $\left(\log _{10}{ }^{*} \beta_{1, \mathrm{H}}=-8.63 \pm 0.05\right.$ and $\log _{10}{ }^{*} \beta_{1, \mathrm{H}}^{\prime}=-9.02 \pm 0.04(\mathrm{La}), \log _{10}{ }^{*} \beta_{1, \mathrm{H}}=-8.37 \pm 0.02$ and $\log _{10}{ }^{*} \beta_{1, \mathrm{H}}^{\prime}=-8.75 \pm 0.04(\mathrm{Pr}), \log _{10}{ }^{*} \beta_{1, \mathrm{H}}=$ $-8.00 \pm 0.5$ and $\log _{10}{ }^{*} \beta_{1, \mathrm{H}}^{\prime}=-8.16 \pm 0.02$ (Ho), and $\log _{10}{ }^{*} \beta_{1, \mathrm{H}}=-7.95 \pm 0.07$ and $\log _{10}{ }^{*} \beta_{1, \mathrm{H}}^{\prime}=-8.12 \pm 0.02$ (Lu)) follows the same behavior along the lanthanide series, that is, the $\log _{10}{ }^{*} \beta_{1, \mathrm{H}}$ and $\log _{10}{ }^{*} \beta_{1, \mathrm{H}}^{\prime}$ increase with atomic number [11]. As observed, the presence of chloride ions and their concentration are important parameters in the determination of the hydrolysis constants.

For a comparison of the values obtained in the present research with others reported previously, the constants should be referred to the same conditions. For example (Table 3), Frolova et al., obtained a value of the $\log \beta_{1, \mathrm{H}}$ of -9.96 [5], in $0.3 \mathrm{M} \mathrm{NaClO}_{4}$ y $0.02 \mathrm{M} \mathrm{Ba}(\mathrm{OH})_{2}$ by potentiometric titration, Guillamount et al. [6], a value of the $\log \beta_{1, \mathrm{H}}$ of -5.7 , in $0.1 \mathrm{M} \mathrm{LiClO}_{4}$ by solvent extraction, and Stepanchikova and Biteikina [7] a value of the $\log \beta_{1, \mathrm{H}}$ of -8.15 in zero ionic strength by potentiometric titration, they all at $298 \mathrm{~K}$. These values are of different magnitude as that reported in this paper, but is of the same order of magnitude as that the Stepanchikova and Biteikina, although ionic strengths and temperatures are different.

\subsection{The Stability Constants of the First Chloride for Holmium Specie}

Chlorides ions compete hydroxyl ions more strongly for formations with Ho(III) because the influence of a $2 \mathrm{M}$ $\mathrm{NaCl}$ than in $2 \mathrm{M} \mathrm{NaClO}_{4}$. The $\log _{10} \beta_{1, \mathrm{Cl}}$ value was calculated by using the first hydrolysis constants obtained in $2 \mathrm{M} \mathrm{NaCl}$ and $2 \mathrm{M} \mathrm{NaClO}_{4}$ and Equation (4). Table 4 shows the values obtained in this research and those

Table 3. Literature data of the first hydrolysis constant of holmium.

\begin{tabular}{|c|c|c|c|c|}
\hline Reference & Method; T, K & Ionic strength (M) & {$\left[\mathrm{Ho}^{3+}\right]$} & $\log \beta_{1, \mathrm{H}}$ \\
\hline 5 & P; 298 & $0.3 \mathrm{M} \mathrm{NaClO}_{4}+0.02 \mathrm{M} \mathrm{Ba}(\mathrm{OH})_{2}$ & {$[0.004-0.009 \mathrm{M}] \mathrm{Ho}\left(\mathrm{ClO}_{4}\right)_{3}$} & -9.96 \\
\hline 6 & SE; 298 & $0.1 \mathrm{M} \mathrm{LiClO}_{4}$ & {$\left[10^{-7} \mathrm{M}\right]$} & -5.7 \\
\hline 7 & SP; 298 & $0 \mathrm{M}$ & {$[0-0.00008 \mathrm{M}] \mathrm{HoCl}_{3}$} & $-8.15 \pm 0.15$ \\
\hline Present work & SP, P 303 & $2 \mathrm{M} \mathrm{NaClO}_{4}$ & $2.5 \times 10^{-4} \mathrm{M} \mathrm{PrCl}_{3}$ & $-8.01 \pm 0.05$ \\
\hline Present work & SP, P 303 & $2 \mathrm{M} \mathrm{NaCl}$ & $2.5 \times 10^{-4} \mathrm{M} \mathrm{PrCl}_{3}$ & $-8.16 \pm 0.02$ \\
\hline
\end{tabular}

P: potenciometric; SE: solvent extraction; SP: spectrophotometric. 
Table 4. Comparison of stability constants of $\mathrm{HoCl}^{2+}\left(\mathrm{M}^{-1}\right)$, taken from the literature and obtained in the present research.

\begin{tabular}{|c|c|c|c|c|}
\hline \multicolumn{5}{|c|}{$\mathrm{Ho}_{(\mathrm{aq})}^{3+}+\mathrm{Cl}_{(\mathrm{aq})}^{+} \rightleftarrows \mathrm{Ho}(\mathrm{Cl})_{(\mathrm{aq})}^{2+}$} \\
\hline \multirow{2}{*}{ Reference } & \multirow{2}{*}{ Method; T, K } & \multirow{2}{*}{ Ionic strength (M) } & \multicolumn{2}{|c|}{$\mathrm{Ho}^{3+}$} \\
\hline & & & $\beta_{1, \mathrm{Cl}}$ & $\log _{10} \beta_{1, \mathrm{C}}$ \\
\hline Wood & $\mathrm{E} ; 298$ & $\mathrm{I}=0 \mathrm{M}$ & 1.86 & 0.27 \\
\hline Millero; Hass et al. & E; 298 & $\mathrm{I}=0 \mathrm{M}$ & 1.99 & 0.3 \\
\hline Present work & SP, P; 303 & $\mathrm{I}=2 \mathrm{M} \mathrm{NaCl}$ & 0.275 & -0.56 \\
\hline
\end{tabular}

E: estimated; P: pH titration; SP, spectrophotometric titration.

found in the literature [16]-[18]. Experimental conditions and the value obtained here are different as those reported by Wood [16], Millero [17] and Hass et al. [18].

The stability constant for the species $\mathrm{HoCl}^{2+}\left(\log _{10} \beta_{1, \mathrm{Cl}}=-0.56\right)$ calculated in $2 \mathrm{M} \mathrm{NaCl}$ ionic strength and with the data reported elsewhere [11] $\left(\log _{10} \beta_{1, \mathrm{Cl}}=-0.0255(\mathrm{La}),-0.155(\mathrm{Pr}),-0.56(\mathrm{Ho}),-0.758(\mathrm{Lu})\right)$ follows the same behavior along the lanthanide series, that is, the $\log _{10} \beta_{1, \mathrm{Cl}}$ value decrease with atomic number [11].

\section{Conclusion}

The hydrolysis constants $\left(\log ^{*} \beta_{1, \mathrm{H}}\right.$ and $\left.\log ^{*} \beta_{1, \mathrm{H}}^{\prime}\right)$ of holmium determined by the two methods were similar. The difference between the values of $\log ^{*} \beta_{1, \mathrm{H}}$ and $\log ^{*} \beta_{1, \mathrm{H}}^{\prime}$, allowed to determine the value of $\log \beta_{1, \mathrm{Cl}}$ of $\mathrm{HoCl}^{2+}$ in $2 \mathrm{M} \mathrm{NaCl}$, showing thus the influence of chloride ions in the ionic strength of this research. Finally, the values of the hydrolysis constant $\left(\log ^{*} \beta_{1, \mathrm{H}}\right.$ and $\left.\log ^{*} \beta_{1, \mathrm{H}}^{\prime}\right)$ and stability constant for the species with chlorides $\left(\log \beta_{1, \mathrm{Cl}}\right)$ of the Holmium, follow the same trend to those of La, Pr, and Lu reported previously.

\section{References}

[1] Ketring, A.R. (2003) Production and Supply of High Specific Activity Radioisotopes for Radiotherapy Applications. Alasbimn Journal, 5, Article ID: AJ19-2.

[2] López-González, H. and Rojas-Hernández, A. (2010) Spectrophotometric Determination of the First Hydrolysis Constant of Praseodymium (III). Journal of the Mexican Chemical Society, 54, 50-57.

[3] Stepanchikova, S.A., Biteykina, R.P. and Sava, A.A. (2013) An Experimental Study of Hydrolytic Behavior of Thulium in Basic and Near-Neutral Solutions. Open Journal of Inorganic Chemistry, 3, 42-47. http://dx.doi.org/10.4236/ojic.2013.32006

[4] Diakonov, I.I., Ragnarsdottir, K.B. and Tagirov, B.R. (1998) Standard Thermodynamic Properties and Heat Capacity Equations of Rare Earth Hydroxides: II. Ce(III)-, Pr-, Sm-, Eu(III)-, Gd-, Tb-, Dy-, Ho-, Er-, Tm-, Yb-, and Y-Hydroxides. Comparison of Thermochemical and Solubility Data. Chemical Geology, 151, 327-347. http://dx.doi.org/10.1016/S0009-2541(98)00088-6

[5] Frolova, U.K., Kumok, V.N. and Serebrennikov, V.V. (1966) Hydrolysis of Ions of the Rare Earth Elements and Yttrium in Aqueous Solutions. Izvestiya Vysshikh Uchebnykh Zavadenii, Khimiya i Khimicheskaya Tekhnologiya, 9, 176179.

[6] Guillaumont, R., Desiré, B. and Galin, M. (1971) Premiere Constante D’Hydrolyse des Lanthanides. Radiochemical and Radioanalytical Letters, 8, 189-198.

[7] Stepanchikova, S.A. and Biteikina, R.P. (2006) Spectrophotometric Study of Holmium Complexation in KOH Solutions at $25^{\circ}$ C. Russian Journal of Inorganic Chemistry, 51, 1315-1319.

[8] Ringbom, A. (1963) Complexation in Analytical Chemistry. Wiley and Sons, New York.

[9] Baes Jr., C.F. and Mesmer, R.E. (1977) The Hydrolysis of Cations. Wiley and Sons, New York.

[10] Ramírez-García, J.J., Fernández-Ramírez, E., Jiménez-Reyes, M., Solache-Ríos, M., López-González, H. and RojasHernández, A. (2003) Solubility and First Hydrolysis Constants of Europium at Different Ionic Strength and $303 \mathrm{~K}$. Journal of Radioanalytical and Nuclear Chemistry, 257, 299-303. http://dx.doi.org/10.1023/A:1024723527305

[11] López-González, H., Solache-Ríos, M., Jiménez-Reyes, M., Ramírez-García, J. and Rojas-Hernández, A. (2005) Effect of Chloride Ions on the Hydrolysis of Trivalent Lanthanum, Praseodymium, and Lutetium in Aqueous Solutions of 2M 
Ionic Strength. Journal of Solution Chemistry, 34, 427-441. http://dx.doi.org/10.1007/s10953-005-5193-7

[12] Legget, D.J. and McBryde, W.A.E. (1975) General Computer Program for the Computation of Stability Constants from Absorbance Data. Analytical Chemistry, 47, 1065-1070.

[13] Gans, P., Sabatini, A. and Vacca, A. (1985) SUPERQUAD: An Improved General Program for Computation of Formation Constants from Potentiometric Data. Journal of the Chemical Society, Dalton Transactions, Issue 6, 1195-1200. http://dx.doi.org/10.1039/dt9850001195

[14] Harris Dan, C. (2003) Quantitative Chemical Analysis. W. H. Freeman and Company, New York and Basingstone.

[15] Pinsuwan, S., Álvarez-Núñez, F.A., Tabibi, S.E. and Yalkowsky, S.H. (1999) Spectrophotometric Determination of Acidity Constants of 4-Dedimethylamino Sancycline (Col-3), a New Antitumor Drug. Journal of Pharmaceutical Sciences, 88, 535-537. http://dx.doi.org/10.1021/js9803981

[16] Wood, S.A. (1990) The Aqueous Geochemistry of the Rare-Earth Elements and Yttrium: 2. Theoretical Predictions of Speciation in Hydrothermal Solutions to $350^{\circ} \mathrm{C}$ at Saturation Water Vapor Pressure. Chemical Geology, 88, 99-125. http://dx.doi.org/10.1016/0009-2541(90)90106-H

[17] Millero, F.J. (1992) Stability Constants for the Formation of Rare Earth Inorganic Complexes as a Function of Ionic Strength. Geochimica et Cosmochimica Acta, 56, 3123-3132. http://dx.doi.org/10.1016/0016-7037(92)90293-R

[18] Hass, J.R., Shock, E.L. and Sassani, D.C. (1995) Rare Earth Elements in Hydrothermal Systems: Estimates of Standard Partial Molal Thermodynamics Properties of Aqueous Complexes of the Rare Earth Elements at High Pressures and Temperatures. Geochimica et Cosmochimica Acta, 59, 4329. 